\title{
DYNAMICS OF PRESENT DAY ORGANIZATIONS TRIGGERING A NEW HR PARADIGM : A CRITICAL ANALYSIS
}

\author{
* Dr. Pradip Kumar Mallik $\quad{ }^{* \star}$ Dr. Pradyumna Kumar Tripathy
}

\begin{abstract}
Continuous change becomes a culture in new age organization. Radical shift in economic, social, cultural and technological environments compels today's organizations to cope with mass obsolescence in traditional organizational structures and designs, products and processes, technology, work culture etc. compel an organization to put thrust on innovations to sustain in an unpredictable and chaotic environment. The urge in the organizations of the day is how to build a highly responsive and adaptive system within that can quickly usher in reengineering in the respective sphere of obsolescence to insulate from the vagaries of upheavals. Indeed, today's organization ought to be busy to tide over turbulent business environment. Moreover, overwhelming information technology (IT) upsurge drives an organization to shift towards generating a knowledgeable work force who can substitute a substantial number of manual workforce to achieve organization's goal. An organization is now a knowledge driven unit. Therefore, the modern organization is more human-machine oriented compared to human dominated in traditional organization. Today, information sharing, knowledge dissemination, multitasking, computerized product designs and production, application of e-commerce etc. are the sprbpeiting forces to remodel organizational behavior. So, the psychodynamics of group behavior has uitidergone $\mathrm{a}$ sea change. The present article makes an

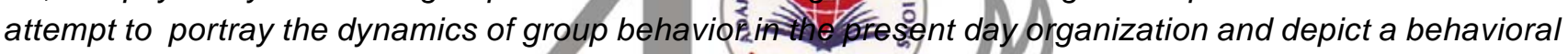
model that truly integrates various interconnecting forces that shape the dynamics of group behavior in a knowledge driven organization.

\section{Introduction}

Change is irresistible. It is an unending phenomenon. It pervades national boundaries to dissipate all over from pole to pole of the globe. It reinvents knowledge, culture, social norms, values, attitudes and behavior. Therefore, tracking change is indispensable to remain unfazed in this ever-shifting environment.

Therefore, adoring the change is an imperative. Denying it means seeing the path of extinction. The choice precipitates to either take guards and stay afloat in the ocean of change or do away with the change and perish. Generally, an organization always remains to be in the battle for sustainability

\section{$\mathrm{Na}+\mathrm{OC}$}

reasons and goes for reengineering drives after
971 to redefining business missions and goals, redeploying resources and remapping strategies to meet the environmental requirements at a particular point of time. For example, economic liberalization in the post 1990s in India swayed many domestic organizations to accept innovations as a survival route to cope with spiraling market competition specifically from the inroads of multinational firms. But the reform measures have opened new vista to the firms. Technology transfer, BPO (Business Process Outsourcing), M\&A's (mergers and acquisitions), FDI (Foreign Direct Investment) etc. have bestowed the firms to spread the business process and operations wherever they desire.
\end{abstract}

* Dr. Pradip Kumar Mallik, Associate Professor - Department of Business Administration Burdwan University, Golap Bag Burdwan,713104 Cell No.: 09831958233 E-mail: Mallik_p59@yahoo.com

** Dr. Pradyumna Kumar Tripathy, Assistant Professor - Department of Business Administration Burdwan University, Golap Bag Burdwan,713104 Cell No.:09434177815 E-mail: pktripathy_in@yahoo.com 
Krishna (2005) articulated the change in financial sector in Indian economy that has facilitated the Indian companies to raise capital from foreign markets. In fact, many Indian firms wrested on innovation drives to perform squarely with multinational firms in this ever-increasing competitive clout. One such example is $\mathrm{HCL}$ Infosystems that by dint of the immense diversity of computing capacities and serving multi media markets and customers have gone for massive product offerings that cater home computers, multimedia applications, high end enterprise level servers etc. So, an organization in changed scenario needs to take massive overhauling of its structure, system, process, technology and behaviour to withstand the heat of globalization. Globalization is such a phenomenon that transforms circumstances as ever to force the organizations to change stances quite frequently and take proactive stands to stay in the wherewithal of the environment. The significant part of this readiness is adaptive response of the organization in all its veins and arteries i.e. in every unit, subunit and individual that has been translated to specific behavioural orientation according to the demand of the situation. But behaviour gets momentum when it is propelled by positive attitudinal force, finds effectiveness when directed to goal and fosters with cohesiveness when the participants of the organization act with the spirit of togetherness. But, what appears to be easy in articulation is difficult in practice. Members of the organization are different individual beings having their own backgrounds, living standards, social profiles, cultural ambiences, political thoughts and personal predilections. Again, within the organization, they have different roles to perform, tasks to accomplish and responsibilities to fulfill and therefore, each employee has to make a balance between his/her inner self that creates a personal world affecting his/her emotions, attitudes and behaviour and external self that engages in assigned activities foregoing some of the urges of the inner world. For example, an employee has a creative mind but is engaged in a routine order checking in purchase department and finds no such intrinsic satisfaction with the job. But he/she has to carry out the role with little or no such motivational involvement. This is just a unitary situation illustrating a forced employee-organization harmonization in an otherwise inappropriate environment within the organization. So, spontaneous behaviour of workforce to contribute towards organizational goal and compulsive behaviour to be part of an organization to work towards organizational goal are different extremes of behavioral dynamics. Here, lies the importance of a firm to place a right person to a right job and secondly, create the right internal environment to facilitate job operations in tune with demand of the job. This is true for all sorts of job situation irrespective of time perspective, past or present organization. In the backdrop of the above, the present paper has made an attempt to cast the following:

a) To understand the behavioural Issues of past and present organizations particularly in context of environmental changes

b) To study the impacts of organizational change on human behaviour. This has firm relevance in respect of IT invasion in present organizations

To profile the human behaviour in the present day organization under knowledge economy.

Past and Present Organization: Distinctive Olssueŝ Influencing Behaviour

Behaviour is a circumstantial phenomenon. It assumes a form at a particular point of time, changes with situational context, modifies in demanding situation and adjusts with the identical situation under contingencies. Behavior, in fact, is the art of expression of individual or a group resulting in both verbal and non verbal responses. Behavior is an outcome of many facets. One's acquired socio cultural back ground, education, immediate environment consisting of both primary (e.g. family) and secondary (e.g. association with clubs) groups, peer relationships and affiliation with various professional and non-professional groups influence one's behavior. Behavior has direct and indirect impacts on performance. A positively motivated person develops an organization centric mind frame that encourages him to manifest close belongingness and commitment to the job. In 
contrast, an employee having a negative frame of mind shows no or little involvement.

Organizational structure has a profound influence on behavior. Traditional organizations were typified by a rigid organizational structure. It advocated vertical chain of command and unidirectional flow of decision. These organizations were bereft of any freedom for its workforce to share information and exchange view with the top level management. Here, work force could only receive commands and instruction to turn them into actions. Authority was mainly vested with the top management and accountability lied with the employees. These organizations had no such drive to develop, grow, innovate, modify, and reorient structurally, functionally, strategically and operationally. Once a practice was developed that was strictly adhered to despite want of organizational efficiency. The management attitude was too narrowed down on revenue generation. Economic success was the sole motive of the organization to remain unperturbed in the market. Employee welfare, social responsibility, contribution to national wealth etc took a back seat. Simply profit earning goal was the motto with no emphasis on customer satisfaction. A mechanical approach to business moulded interpersonal relationship between blue and white collar employees. Expectation of employees was confined to wage earning and incidental benefits. As a result, motivational urge of them was of lower order. Extrinsic satisfaction was guaranteed to a section of employees by monetary incentives but intrinsic satisfaction was left in the lurch. Safety and security of job was not a priority of the management, rather it was provided within the legal parameters of labor acts but flouting it under the cover of formal observance of the law was common. Trade unions used to safeguard the interests of the employees but astute management at times played partisan mechanism to disarray the trade union movement and therefore, the dignity and respect of employees was at stake. The talent, skill and specialization of working groups was underestimated leading to loss of motivation and morale of the workforce. Innovation was a distant reality of the organization. The organization, in general, seldom practiced product and service development, process improvement, system upgradation and operational excellence. Competition in the market was not so fierce to compel firms to make changes in process, structure and system. In fact, there was no such need felt to moderate the organizational functioning and working procedures. A protected market situation made a firm sluggish on developmental prospects. As customers had scanty alternatives for goods and services, the companies always took upper hand to hold customers in their folds and dictate terms to oblige them to act. In fact, sellers' market prevailed unjustly making buyers helpless on the choice of the product. This unfair business culture got a jolt upon confronting the metamorphic industrial revolution that paved way to large number of firms to usher in with vigour in production and distribution of products and services. Old custodians in the business had a learning experience. So, simply by taking customers for a ride couldn't be a long term proposition. Cormpetition compelled the players in business to pay attention to quality of the products/services, customers' needs and expectations and redirecting the business to make it customer focused. Gradually a customer centric business culture flourished in the industrial climate to impinge the firms to sit up and take notice the way the business so far was being operated. Not only the way of doing business but also, the organizational structure, function, system and work operations needed a revamping to sport a new look in view of the massive overhaul in the market dynamics leading to a transition from a seller's market to buyer's market,fighting a battle to reach customers with the right offer in time outpacing competitors, retaining the customers, creating brand loyalty and so on. Organizations realized it first that unless a change in the organizational culture was initiated, such venture wouldn't be possible. Now, culture is not a single entity that can be changed overnight. In fact, culture is a conglomeration of all business fundamentals that have a bearing on the societal position of the business that, if present in right proportion, the goals of the business can't be difficult to achieve. Culture gives birth to customs, 
values, ethos, etc. that shape and mould organizational behaviour. Culture generates mutual trust and coordination among organizational participants functioning along laterally, and vertically under organizational structure. It acts in tandem with vision and mission of the business. It gives pragmatic meanings to the objective statements. Therefore, culture is the index of the health of the business. Culture facilitates a business to decide the long - range goals of it.

So, old and new organizations at the core differ in terms of practicing organizational culture. Old organizations were inner centric or centralized in terms of decision making whereas present organizations follow more participative and cooperative culture where employer- employee relationships are based on information sharing and empowerment rather than control from the apex.

Under participative culture, a problem of one department becomes a trouble for the whole organization. For example, poor sales in one territory turns out to be the bottleneck of the sales organization despite effective sales performance in other territorial units. An underperformance in one part of the assembly line will jeopardize the production of automobiles limiting the production efficiency of the automobile company. So difference in culture between dated and present organizations decides dissimilar work behavior in the two.

\section{Impact of Organizational Change on Human Behaviour}

Human behavior has undergone a radical shift with the changes in organizational structure, design, culture and system. Present day organizations demand more responsive and sensible behavior from the human resource in order to adapt with evershifting business landscape characterized by sky rocketing expectations of customers, spiraling nature of competition, socio -economic transformation, cultural transition and most prominently digital revolution. Though machines assume a significant role in running and coordinating today's organizations, human role in it can't be undermined. In fact, human resource is treated as intellectual capital to a firm to add operational efficiency and competitive advantage.

Human capital is the nerve centre of the organization. The pulse of the organization throbs around it. Organization save human resource is ship without sailors. The need for human capital is therefore paramount to the existence of the organization. Now, the crucial question is how the human capital can be leveraged to the optimal extent to support other resources within the organization and facilitate boundary -spanning activity outside it. Knowledge of human resource is the driving force to stimulate system-process coordination within the firm and organization-stakeholder integration outside it. Knowledge places a premium on relationships. Along with knowledge, skill, experience, attitude, commitment and ethics are vital links to human capital. Simply, knowledge can't be productively used unless skill supplements it. Experience adds value to the knowledge and skill. Attitude in combination up omplth knowledge, skill and experience gives rise to 7 human behavior. Commitment indulges human capial to stay affirmed to goal achievement. Ethics warrants morality in business operations. GaL EOmmitment to ethical behavior is the hallmark of perpetual success of the organization ( Schermerhorn et.al, 2006).

Present organizations are bestowed with the most gifted blessing of IT revolution that has made a stark comparison between these and past organizations. It is not just treated as a scientific innovation, but also conceived as a culture and custom. IT has made a radical turnaround in every sphere of the business firm and its vast capacity has shaken up almost each function of the firm. Traditional paper and file has almost seen bid adieu and humbly made room for paperless office (e.g. Microsoft) and courtesy goes to IT. Production, marketing, purchase, finance, R\&D and every where IT has made a deep inroads and stormed to change the age old and hackneyed practices or operations and brought in speed, accuracy, precision, efficiency and value creations. In many a firm, production department is practically IT controlled and finished products are jutted out with remote sensing devises 
with one or two IT specialists. In finance section, accounting, billing, auditing, tax estimation etc. are at the fingertip of IT. Marketing and sales also are witnessing makeover by adoring cyber marketing, direct marketing, and network marketing etc. where customers can be reached in nanosecond time lag. Purchase department is also endowed with IT as most of its operations like ordering, delivering, shipping, warehousing, packaging, requisitioning, procuring etc. are smoothed out by the grace of one and only IT. So, the very pertinent question that reverberates in every bit of the organization is the necessity of man- power that, so far was the central axis of the organization. Welcome IT at the cost of human resource is now the new mantra of the present day organization. The so called living resource of the firm is now at the point of peril as IT has been decimating the power of the human capital. The result is quite disheartening. Downsizing, delayering, rightsizing, outsourcing practices are commonplace in business firms. Dessler (2008) envisaged some of the prominent changes to typify the modern organizations. Dejobbing is one such change where an employee is advised to broaden his/her job responsibility beyond the specified job description. Similarly, the change from pyramidal to flatter type organizational structure, encouraging wider span of control and fewer vertical levels and inculcating boundaryless organization, thus effacing the narrow span of compartmentalized approach and integrating the work functions of specialization units, spreading the work culture of autonomous and cross functional work teams and reengineering of business processes abridges the modern organization from traditional ones. Jauhuri ( 2003-04) traced out the structural revamp of Nirulas, established in 1934 with diversified groups having a chain of splendid hotels, water service treatments, family style restaurants, ice cream parlours, pastry shops and food processing plants in India reorganized its structure in 2001 with the extension of the number of general managers for engineering, finance, human resource and purchase for which the core functions such as sales, marketing, new projects, operations and training were benefited. Voluntary retirement, golden handshake, pink slip are haunting around everywhere in the job market putting a question mark on the future of job opportunity, prospect of the young generation by showing them the exit door. So, where organizations can run without human power, what is need for a discourse on organization behavior? By organization behavior, we mean understanding, assessment and prediction of human behavior in organizations. So, when human elements in organization are shrinking at an abysmal proportion, arguing on human behavior is how far pragmatically drawn upon? So time has come to start hair splitting analysis of human behavior at work in present juncture and essay on organization behavior that is set to cast a new look.

\section{Human Behavior in present day organization: A Critical Study}

Human Behaviour is the driving force of the organization. Thus, human resource is instrumental in phoving the organization functionally, maneuvering Itstrătegically and benefiting stakeholders equitably. so Organization sans human components is a myth. GaLlefrespective of time, space and environment, human resource can't be dismembered in no uncertain terms. Human component is considered as knowledge resource of the organization. Today's machine dominated industries can't rule out the importance of knowledge resource. A machine is hardware of an organization. Unless it is driven by knowledge it can't produce any result. A machine can only act at the instance of knowledge. A machine can only produce when right instructions are fed to it. A machine can provide long term service when it is maintained with engineering acumen. So, needless to mention that human component in a modern industry is a living instrument like traditional one. But, the interesting question that looms large is the distinction of the type and character of human resource of the two opposing industries. Traditional industry was labor intensive and labors were the dominant force to run the organization. Today labor has been substituted by machine and the labor intensity is reduced to a great extent. Again in traditional industries a supervisor or manager was 
deemed to be the instructor and labor force regarded him/her as the mentor. He/she was supposed to be repository of knowledge. He/she delivers instruction backed by knowledge and work force obeys it with spontaneity. So, the modern industries are the offshoot of the knowledge driven society. Knowledge driven society is such a social context with global perspective where information, knowledge, wisdom are the sources of exchanging ideas, concepts, views, technology, culture and relations culminating in a universal paradigm of integration. Knowledge impregnated society gives birth to new industrial facade where organizational behavior is recomposed on human-machine dyadic and deterministic base and understanding and rationale of human behavior at work relates to knowledge acquisition (learning behavior), processing ( synthesis of machine centric behavior that a machine can understand) and distribution ( behavior that directs machine to act) to machine on individual plane and knowledge sharing, knowledge transfer, mentoring and persuasion on group side. Figure 1 represents the dyadic relation between man and machine in an organization.

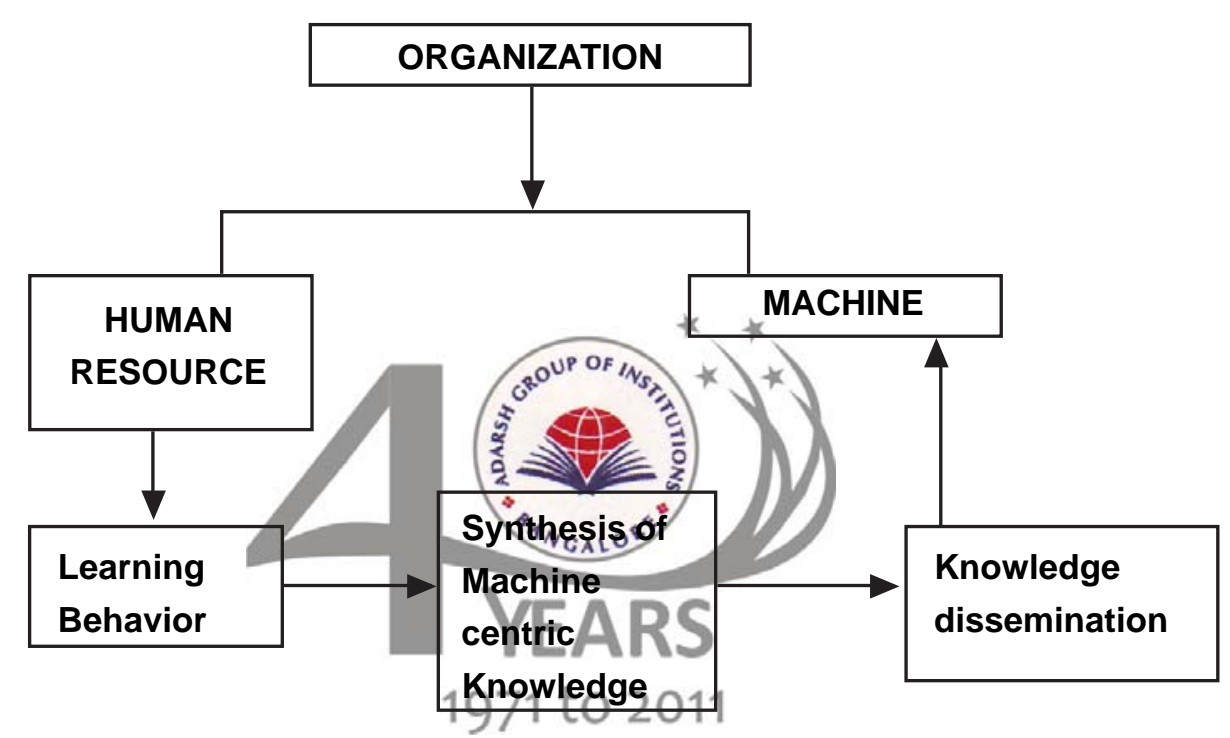

Figure: I: Man-Machine Dyad: A Fulcrum of Modern Day Organizational Behavior

\section{Behavioral Dynamics in Present Day Organizations: A Man-Machine Interface.}

Interpersonal behavior is poised to take a significant step in view of invocation of machine in modern firms. This has led to a change in organizational behaviour impacting people's emotion, attitude, perception, learning, peer relationships, coalition, conflict resolution etc. The central notion of behavior has been rechristened to evolve a new set of ideas, meanings, constructs and axioms to garner a different kind of psychodynamics where emotional components of behavior get marginalized giving space to rational components, learning via mentoring by superiors is replaced by self taught learning, perception of the language of machine rather than human works more in present day behavioral dynamics. A machine is instrumental in networking employees. Machine meddles between employee to employee behavior. So, the crucial questions are what the contents are and what's the structure of the psychodynamics of the present day organization? How it generates effective organizational behavior? As an organization is machine dominated, dynamics of the organization gets more titled towards man-machine coordination where psycho-social relationships among organizational participants orient towards sharing knowledge and skill rather than emotions. But 
psychology can't be ruled out because knowledge or wisdom needs psychic push coming out of learning, attitude to new job environment etc. to blossom. But, psychological pushes gradually are taking backseats giving room to more machine centric human behaviour where productivity and efficiency speak the final word. Less psychological and more rational elements are involved in the current behavioral dynamics within the organization. But, interpersonal relationships has wore a new mantle surrounding machine culture.

Interpersonal relationship is the one of the major thrusts to attain healthy organizational climate. An organizational climate is determined by the collective mindset of workforce with respect to management attitude to employees, administrative process, cohesiveness between employees and management, perception of employees on upward mobility and recognition in organization and outside. Climate shapes culture in the organization and is expressed by shared beliefs, attitudes, behaviors, relationships etc. In traditional organization, organizational climate and culture find relevance in view of perpetuity and inheritance of these among participants along time. But, the sudden spurt of mechanization in the corporate sector sets forth a big question before climate-culture interface. But, whatever the circumstances might be, climate and culture possess human face despite lesser human involvement in machine dominated organization. Luthans (1989) viewed that culture inherits some important characteristics like observed behavioral regularities, norms, dominant values, philosophy, rules and organizational climate that lend a specific pattern of behavior to the participants of the organization. Robbins and Sanghi (2006) opined that organizational culture tells employees perceive the characteristics of an organization's culture, not with whether or not they like them. The debatable question, therefore, is whether culture and climate still are necessary ingredients of the organization or these have lost its sheen.? Actually climate and culture are incessant psychological assets of the firm. These remain and flow within the DNA of the organization. These trickle down to employees as well. These sustain and transcend from time to time regardless of innovation sprees and technological revolutions. Still, culture needs rejuvenation without hurting the core aspect of it. For example, traditional organizational culture believed in autocracy, family based organizations, laid back style of management and a kind of secretive environment where as modern firms are flexible, rely on team based management, dispersed ownership and more transparent and rational in work culture ( Aswathappa, 2007). The core culture can be better understood from the vision the organization envisages and mission it aims to achieve. A vision statement reflects the core culture of the organization. For example, hospitality is a key focus of air lines organization. An airline company can envision zero defect hospitality for its passengers and for its sake, technology, staff, personal relationship with airport authorities, arrangement with hotels, motels etc. in the vicinity of airports, escort of passengers, valued assistance within the air ports for official formalities etc. need quality overhaul to equate even with quality standards expected from Tastiglious passengers. What the company currently pursues to uplift the service quality is definitely a component of the mission. Objectives quantify the missions. Objectives provide directions to the business. Objectives envision the intended oytcomes of the business. Modern business organizations are strong votaries of vision, mission and objectives. In fact they carry out the legacy of the traditional organizations intact. Old but well nurtured traditions of the organizations are the boons of the modern ones. Well known corporate houses like Tata, Godrej, Hindustan Unilever, Oberoi, etc. are the forerunners in carrying over the so called image very earnestly since their reputation was built up in the industry. The new generation managers are trying their best to forsake the ills of old tradition while restoring the goods of it. Without invoking any change in the image factors, these managers make environment specific changes in their products or services, processes, designs etc. only to match with present business conditions.

The most noticeable change in corporate philosophy has been reflected in the governance of organization where admiration to share holders' 
equity funds, transparency in financial operations, shareholders' right to know the financial results from time to time, social responsibility of business, environment protection, safeguard of consumers' interests, maintaining ethics in business etc. People may argue on the presence of corporate responsibility in society where stakeholders belong to but in olden days these featured in corporate missions were far from reality for many organizations. Now, corporate governance is the survival mechanism and its essence transcends among not only the top-level managers but also employees of the firm. It also spreads among stakeholders who know organization to the core from the investment, returns on investment, position in the stock market, standings on other financial parameters etc. Earlier shareholders were more risk prone due to absence of right guidelines and lack of information on the market. Now stakeholders have become more knowledgeable by the grace of media and host of other factors. They can quickly assess the future health of the organization. So investment behavior has undergone a radical change in the present business environment too.

\section{Conclusion}

Behavior is a time linked human characteristic. It varies across situations also. An individual behaves in a way whenever he is in the family situation. He naturally is more informal and applies grapevine communication. However, he within the organization generally measures up the situation and behaves accordingly. Again, behaviour of one individual is different from the other in identical situations. An employee, whenever getting harsh treatment from his boss, is emotionally broken. In an identical situation, another employee may react more rationally. Group behavior is the combined effect of the behavior of the individuals constituting the group. The behavior of sales team in a company is a group behavior. An individual's behavior may not be in unison with the group behavior still he has to adjust his behavior in the interest of the group.

Modern day organizations thrive on the platter of man-machine coordination. Here technical skill of man speaks more to run the machine. Individual technical brilliance and attitude is important. So far as group behaviour is concerned, today's organization represents a handful of specialists that are adept in their respective fields but act in tandem to reach the goals. So, group behavior hasn't lost its gravity in new age. For example, in the sales team, one has the knowledge and skill to handle customers' technical queries and solve technical snags an equipment generates. Another sales person looks after the commercial dealings. Both work towards customer satisfactions but by making different value additions. Customer satisfaction at a profit is the goal of the organization but how concertedly that can be reached is the focus of the present day organization.

In fact, the word modern is relative. What is modern today will be hackneyed tomorrow. As business environment is fast moving, the modernity becomes transient. Business plans, strategies, policies, processes etc. can't follow any thumb rules. Spontaneous changes of these with the transformation of business scenes and conditions is the order of the present day business. Organizational behavior, therefore, has come to crossroads to accept new theories and practices ofand moderate the old ones to be consistent with the present day requirements. Continuous innovation of Ofanizational behavior is the slogan of the day.

\section{Beferences}

Aswathappa, K (2007). Essentials of Business Environment. Himalaya Publishing House, Mumbai.

ODessiler, G ( 2008). Human Resource Managenent. PHI, New Delhi.

Jauhari, V ( 2003-04) Growth Opportunities in an Emerging Sector-The Case of Nirulas, Journal of Services Research, Vol3, No.2., pp.125-148.

Krishna, C.V (2005). The Importance of External Commercial Borrowings \&Indian Experience,. Synergy, Vol.3, No.1, pp. 16-31.

Luthans, F ( 1989). Organizational Behavior, McGraw-Hill International Editions, New York, Toronto.

Robbins, P.S.and Sanghi, S (2006). Organizational Behavior.Pearson, New Delhi.

Schermerhorn,Jr., J.R., Hunt,J.G. and Osborn,R.N (2006). Organizational Behavior. Wiley India, New Delhi. 